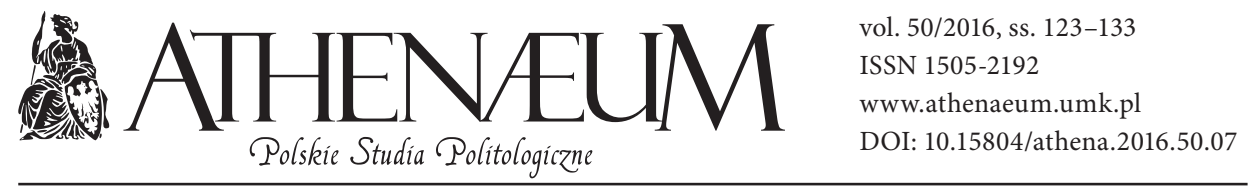

\title{
FENOMEN BOKO HARAM. AFRYKAŃSKI KALIFAT ZAGROŻENIEM DLA BEZPIECZEŃSTWA MIĘDZYNARODOWEGO
}

\author{
BOKO HARAM PHENOMENON. \\ AFRICAN CALIPHATE AS A THREAT \\ TO INTERNATIONAL SECURITY
}

Marta S. Stempień*$$
\text { ABSTRAKT }
$$

Społeczność międzynarodowa jest nieustannie zmuszana do konfrontacji z zagrożeniem ze strony islamskiego terroryzmu w różnych częściach świata, w tym w wielu częściach Afryki, jak np. w Nigerii, gdzie dżihadystowskie powstanie Boko Haram przekształciło się w konflikt regionalny. W przeszłości grupa była powszechnie określana jako sekta religijna, obecnie uznaje się ją za organizację terrorystyczną. Pomimo różnic w metodach działania jest porównywana do Al-Kaidy, Państwa Islamskiego i Talibów. Od marca 2015 roku należy do sieci prowincji Państwa Islamskiego, w związku ze złożeniem przysięgi wierności kalifowi Abu Bakrowi Al-Baghdadiemu. Niniejsza publikacja ma na celu przeanalizowanie fenomenu Boko Haram oraz połączenia jej ze zjawiskiem tworzenia samozwańczych kalifatów. Artykuł uwzględnia nigeryjską tożsamość religijną, etniczną i regionalną, aby wskazać oddziaływanie Boko Haram na bezpieczeństwo międzynarodowe.
\end{abstract}

\begin{abstract}
The international community must constantly confront the threat posed by terrorism in various parts of the world, including many parts of Africa, also in Nigeria, where a jihadist insurgency of Boko Haram turned into a regional conflict. In the past, the group was commonly defined as a religious sect, now it is recognized as a terrorist organization. Despite the differences in the methods of operation, it is compared to the Al-Qaeda, Islamic State, and Taliban. Since March 2015, it is part of the Islamic State province network, in conjunction with the pledge of allegiance to caliph Abu Bakr Al-Baghdadi. This publication aims to analyze the phenomenon of Boko Haram and its connection to the occurrence of creation of self-appointed Islamic caliphates. It takes into account the religious, ethnic and regional identities to indicate Boko Haram's impact on international security.
\end{abstract}

* Uniwersytet Przyrodniczo-Humanistyczny w Siedlcach, Instytut Nauk Społecznych i Bezpieczeństwa. 
Słowa kluczowe: bezpieczeństwo międzynarodowe, Boko Haram, kalifat, Nigeria, islamski terroryzm
Keywords: international security, Boko Haram, caliphate, Nigeria, Islamic terrorism

\section{WPROWADZENIE}

Mimo że obecnie fundamentalistyczne grupy terrorystyczne często wykorzystują religię instrumentalnie, to współczesne wydarzenia na arenie międzynarodowej, w tym w Nigerii, to niewątpliwie szczególnie ważny i ciekawy moment w historii islamu. Całkowicie abstrahując od kwestii terroryzmu, zaangażowanie muzułmanów na arenie politycznej na całym świecie znacząco rośnie, a wizja wzrostu roli islamu na arenie międzynarodowej stała się już faktem. Ponadto ponad połowa wyznawców islamu mieszka na muzułmańskim południu, które obejmuje: Afrykę Wschodnią, Afrykę Zachodnią, Bangladesz, Etiopię, Filipiny, Indonezję oraz Sudan (Bulliet, 2013, s. 3) ${ }^{1}$. Oczywiście na całym świecie muzułmanie skoncentrowani są na dążeniu do wzmocnienia roli własnej religii na arenie politycznej, jednak wydarzenia w Nigerii pokazują, że społeczność międzynarodowa powinna więcej uwagi poświęcać muzułmańskiemu południu, w tym Afryce Subsaharyjskiej, by nie pozostawić tego regionu z problemem ekspansji idei kalifatu i islamskiego terroryzmu, w konsekwencji doprowadzając do jego izolacji. W obliczu tak licznych problemów, z którymi boryka się Zachód, m.in. niekontrolowanego napływu uchodźców czy ataków terrorystycznych, jest to niezwykle trudne zadanie.

Społeczność międzynarodowa powinna skoncentrować się również na organizacji Boko Haram, która jest symptomem statusu Nigerii jako państwa upadającego ${ }^{2}$, ubóstwa kraju, dominacji islamskiej północy nad chrześcijańskim południem oraz międzynarodowych powiązań z innymi grupami terrorystycznymi. Niewątpliwie stanowi ona zagrożenie dla stabilności całego kontynentu afrykańskiego, ale także bezpieczeństwa międzynarodowego. Dzięki analizie fenomenu organizacji, społeczność międzynarodowa może pomóc Nigeryjczy-

\footnotetext{
${ }^{1}$ Muzułmańska Północ obejmuje natomiast: Afrykę Północną, Egipt, Bliski Wschód (z wyjątkiem południowej Arabii), północne Indie, Afganistan, Azję Środkową oraz Turcję.

${ }^{2}$ Nigeria znajduje się na 17. miejscu w Indeksie Państw Kruchych, tworzonym przez analityków periodyku Foreign Policy i organizacji Fund for Peace (W 2014 roku zmieniono nazwę indeksu, słowo failed zastąpione zostało terminem fragile, które po polsku można tłumaczyć „wątłe”, „kruche”, co miało na celu przekształcenie pejoratywnego terminu państwo upadłe i nadanie mu łagodniejszego znaczenia).
} 
kom w budowaniu państwa wolnego od terroryzmu, kryzysów humanitarnych, pokojowo rozwiązującego konflikty, a co za tym idzie, stanowiącego mniejsze wyzwanie dla budowania trwałych fundamentów pokoju. Jednakże często analiza tejże problematyki, ignorująca kontekst historyczny, regionalny i etniczny, który ukształtował nigeryjską tożsamość religijną, jest zbyt prosta, by określić kompleksowe przyczyny fenomenu działalności Boko Haram. Takie opracowania ignorują również aspekt społeczno-gospodarczy, przede wszystkim nierównowagę gospodarczą między stosunkowo bogatym południem i biedną północą Nigerii.

Celem niniejszego artykułu jest kompleksowe zbadanie fenomenu Boko Haram, w tym aktualnych przejawów nigeryjskiego fundamentalizmu religijnego, oraz odpowiedź na pytanie, czy przedstawione fakty mogą świadczyć o tym, że zagrożenie ze strony kalifatów ulegnie nasileniu w najbliższej przyszłości.

\section{WSKRZESZENIE IDEI ISLAMSKIEGO KALIFATU W AFRYCE}

Przed końcem 1950 roku, najwięcej reżimów na świecie znajdowało się na Bliskim Wschodzie. Muzułmańscy dyktatorzy wojskowi, początkowo sprawiali mylne wrażenie postępowości i oddania swoim krajom, tak jak wcześniej robili to Adolf Hitler, Benito Mussolini czy Józef Stalin. Bliskowschodni faszyzm, zazwyczaj w formie rządów wojskowych, krył się pod płaszczykiem świeckiej tożsamości narodowej prezentowanej Zachodowi. Z czasem wzrost wpływu tyranii spowodował przebudzenie muzułmańskiej populacji, co pobudziło instynktowne skłonności do wykorzystania religii jako siły naprawczej wobec destabilizacji politycznej. Zgodnie z tym założeniem, podczas gdy tyrania rośnie w siłę, ruchy opozycyjne powinny wykorzystywać religię i odwołać się do prawa, w tym przypadku islamskiego, by ją ograniczyć i wprowadzić bardziej sprawiedliwy ład. $\mathrm{Na}$ Bliskim Wschodzie, z biegiem czasu koncepcje ruchów i partii, wspierających ideę rządu islamskiego, jak również propozycję utworzenia kalifatu, stały się coraz bardziej popularne ${ }^{3}$. To również uwidoczniło się w trakcie tzw. Arabskiej Wiosny, która wybuchła w regionie Afryki Północnej i Bliskiego Wschodu (Middle East and North Africa - MENA). Na skutek wydarzeń zwanych również

${ }^{3}$ Po śmierci Mahometa, zwierzchnictwo nad światem muzułmańskim przejęli kalifowie, aż do czasu, gdy Mustafa Kemal Ataturk po upadku Imperium Ottomańskiego zniósł kalifat (w 1924 roku) i utworzył świeckie państwo tureckie. Od tego czasu do 2014 roku - utworzenia samozwańczych kalifatów przez Państwo Islamskie i Boko Haram - kalifat się nie odrodził. 
Arabskim Przebudzeniem - termin spopularyzowany przez media zachodnie na początku 2011 roku kiedy sukces rewolucji w Tunezji wywołał antyrządowe protesty w większości krajów arabskich obszaru MENA - społeczeństwo odkryło, że popularne działania mogą doprowadzić do upadku dyktatur, co początkowo dobrze wróżyło długoterminowym perspektywom politycznym państw dotkniętych rewolucjami (Altomonte, Ferrera, 2014). Obecnie widzimy, że doprowadziło to do głębszej destabilizacji regionu, który boryka się z większym zagrożeniem dla bezpieczeństwa - ekspansją Państwa Islamskiego, a to ośmiela do bardziej radykalnych działań inne struktury i organizacje terrorystyczne, $\mathrm{w}$ tym właśnie Boko Haram, pomimo że Nigeria nie jest państwem arabskim. Początkowo nigeryjskiemu ekstremizmowi sprzyjała również międzynarodowa koniunktura, w tym wojna domowa w Libii oraz utworzenie kalifatu w Mali, które podobnie jak Nigeria nie jest krajem arabskim ${ }^{4}$.

Boko Haram wykazuje silne powiązania z innymi grupami islamskich terrorystów w Afryce, szczególnie z północnej Mali i Somalii. Posiada również kontakty z międzynarodowymi organizacjami, w tym Al-Kaidą, zwłaszcza jej filią działającą w afrykańskim Maghrebie i Sahelu - Al-Kaidą Islamskiego Maghrebu (Al-Qaeda in the Islamic Maghreb - AQIM) (Adibe, 2013, s. 10, 13-14), ale także z libańskim Hezbollahem czy afgańskimi Talibami. Nigeryjscy bojownicy, nawiązując kontakty z innymi ugrupowaniami terrorystycznymi, stworzyli sieć powiązań finansowych, szkoleniowych, rekrutacyjnych i logistycznych, która zagraża nie tylko integralności i bezpieczeństwu Nigerii czy całej Afryki, ale także Zachodowi i bezpieczeństwu międzynarodowemu (Adebayo, 2014, s. 481).

Zatem Boko Haram czerpie idee od innych islamskich organizacji terrorystycznych. Część badaczy uważa, że to właśnie ogłoszenie kalifatu przez Państwo Islamskie w Iraku i Lewancie (Islamic State of Iraq and Levant - ISIL) ${ }^{5}$, które miało miejsce 29 czerwca 2014 roku, mogło wpłynąć na decyzję Boko Haram, o utworzeniu własnego - afrykańskiego kalifatu. Został on proklamowany przez Abubakra Shekau - lidera ugrupowania, 24 sierpnia 2014 roku, w Gwozie i od tego czasu systematycznie zwiększa swoje terytorium (Nigeria's Jihadists. The other caliphate, 2014, s. 50).

\footnotetext{
${ }^{4}$ Kalifat w Mali został utworzony wiosną 2012 roku. Został jednak zlikwidowany przez francuską interwencję wojskową w styczniu 2013 roku. Zanim miało to miejsce, bojownicy z Boko Haram walczyli w Mali, zdobywając doświadczenie oraz broń.

${ }^{5}$ Po ogłoszeniu kalifatu pod nazwą „Państwo Islamskie” zmianie uległa również nazwa organizacji - usunięto wyrazy „Irak” oraz „Lewant” („Al-Sham”), a na czele kalifatu stanął szejk Abu Bakr al-Baghdadi.
} 
Jednak znacznie większy wpływ miała tu historia Nigerii, która lepiej tłumaczy pochodzenie przemocy etnicznej i religijnej w tym kraju. Istnieje również wiele teorii tłumaczących samo pojawienie się sekty. Nie ma także jednomyślności odnośnie przyczyn radykalizacji grupy. Niektóre tezy określają Boko Haram jako objaw upadłości bądź chylenia się państwa ku upadkowi. Inni obwiniają biedę i niestabilne rządy, podczas gdy niektórzy lokalizują przyczynę utworzenia grupy we frustracji i agresji członków sekty, rozczarowanych sytuacją wewnętrzną państwa. Gdy grupa powstała, położenie muzułmańskich mieszkańców było niezwykle trudne, a konfiguracja władzy politycznej była niekorzystna dla północy (Adibe, 2013, s. 12-13).

Niezależnie od przyczyn powstania i radykalizacji Boko Haram oraz wpływu innych struktur dżihadystowskich, w tym Państwa Islamskiego, na nigeryjską organizację, prawdą jest, że zrozumienie samej idei kalifatu (w tym analiza syryjsko-irackiego kalifatu, posiadającego prowincje w innych regionach świata) może pomóc w zrozumieniu jego nigeryjskiego odpowiednika. Jednak nie wolno ignorować samego pochodzenia Boko Haram, które ściśle wiąże się ze specyfiką i destabilizacją państwa, bo utracona zostanie nadzieja na stłumienie groźnej ideologii nigeryjskich terrorystów, dążących do utworzenia kalifatu znacznie większego niż obecne, samozwańcze Państwo Islamskie.

\section{BOKO HARAM - "LUDZIE ZAANGAŻOWANI W KRZEWIENIE NAUK PROROKA I DŻIHADU"}

Boko Haram została założona w 2002 roku. Grupa rozpoczęła działalność jako meczet w północno-wschodniej Nigerii, który głosił poglądy separatystyczne wśród lokalnej społeczności muzułmańskiej, zgodnie z restrykcyjnymi zasadami wahabizmu, islamskiego fundamentalistycznego ruchu religijnego i politycznego, powstałego w XVIII w., dążącego w swoich działaniach do powrotu do źródeł tj. pierwotnej czystości islamu, surowości obyczajów (więcej na temat powiązań wahabizmu z Boko Haram, zob. Bederka, 2014). Nazwa organizacji w języku polskim może zostać zinterpretowana jako: „edukacja zachodnia jest grzechem” lub „zachodnia cywilizacja jest zakazana”'. Jej członkowie wolą jednak używać arabskiej nazwy - Jama’atu Ahlis Sunna Lidda’awati Wal-Jihad, która oznacza

${ }^{6}$ Odrzucenie zachodnich wartości, przede wszystkim zachodniej edukacji ma swoje źródło w czasach kolonialnych, kiedy kalifat Sokoto był jednym z najpotężniejszych imperiów w Afryce 
„Ludzie Zaangażowani w Krzewienie Nauk Proroka i Dżihadu” (Adibe, 2013, s. 10). Początkowo Boko Haram jako fundamentalistyczna sekta islamskich sunnitów propagowała w nigeryjskim społeczeństwie ścisłą formę szariatu. W 2009 roku, pod wpływem wahabizmu, przekształciła się w grupę salafickich dżihadystów. Wcześniej zaangażowana była w kilka aktów przemocy, ale od tego czasu jest odpowiedzialna za około 3500 zgonów wśród ludności cywilnej. Bez wątpienia brutalność członków organizacji wzrosła po śmierci jej twórcy i lidera - Ustaza Mohammeda Yusufa, gdy dowództwo przejął Abubakr Shekau (Boko Haram, August 21, 2013).

Skalę terroru pokazuje miejsce Nigerii w Globalnym Indeksie Terroryzmu z 2014 roku (tabela 1). Znalazła się ona na czwartym miejscu pośród 162. państw. W 2013 roku, wśród dziesięciu najbardziej krwawych ataków terrorystycznych na świecie, trzy miały miejsce właśnie w Nigerii, a dokonało ich Boko Haram. W pierwszym z nich, w Beni Shiek, 17 września 2013 roku zginęły 142 osoby. Wówczas uzbrojeni napastnicy, ubrani w mundury wojskowe, przygotowali nielegalne punkty kontrolne, na których zatrzymywali i rozstrzeliwali ludność cywilną. W dwóch pozostałych atakach, w Damatura i Bama, zginęło łącznie 195 osób (Global Terrorism Index Report, 2014, s. 84).

Tabela 1. Główne organizacje terrorystyczne w pierwszych pięciu państwach Globalnego Indeksu Terroryzmu (GTI).

\begin{tabular}{|c|c|l|}
\hline Państwo & Pozycja w GTI 2014 & \multicolumn{1}{|c|}{ Główne organizacje terrorystyczne } \\
\hline Irak & 1 & $\begin{array}{l}- \text { Państwo Islamskie/Państwo Islamskie w Iraku } \\
\text { i Lewancie } \\
- \text { Al-Kaida }\end{array}$ \\
\hline Afganistan & 2 & - Talibowie \\
\hline Pakistan & 3 & $\begin{array}{l}- \text { Tehrik-i-Taliban Pakistan } \\
- \text { Laszkar-e-Dżangwi }\end{array}$ \\
\hline Nigeria & 4 & - Boko Haram \\
\hline Syria & 5 & $\begin{array}{l}- \text { Dżabhat an-Nusra (Front Obrony Ludności Lewantu) } \\
- \text { Państwo Islamskie/Państwo Islamskie w Iraku } \\
\text { i Lewancie }\end{array}$ \\
\hline
\end{tabular}

Źródło: Opracowanie własne, na postawie Global Terrorism Index, 2014.

Subsaharyjskiej. Obejmował część obecnej północnej Nigerii, Nigru i południowego Kamerunu. Uległ jednak europejskiej kolonizacji w XIX wieku. Więcej na temat historii kalifatu w: Bulliet, 2013. 
Stopień zagrożenia stwarzany przez Boko Haram pokazuje również raport Amnesty International, który wykazał, że w ataku na wioskę Baga z 3 stycznia 2015 roku, zginęło około 2.000 cywilów. Zdjęcia satelitarne wskazały rozległe zniszczenia, a atak był najprawdopodobniej jednym z najbardziej krwawych działań Boko Haram. Według Amnesty International od 2013 roku nigeryjska organizacja pozbawiła życia co najmniej 5.400 mieszkańców północnej Nigerii, choć rzeczywista liczba ofiar może być znacznie większa (Blind to Bloodshed. The insurgency in Nigeria, 2015, s. 48-49; Boko Haram at glance, 2015).

7 marca 2015 roku przywódca nigeryjskich dżihadystów złożył przysięgę wierności Państwu Islamskiemu poprzez umieszczenie nagrania na Twitterze. Została ona przyjęta przez rzecznika IS - Abu Muhammada al-Adnaniego al-Shamiego, który pod koniec marca 2015 roku ogłosił powstanie nowej prowincji kalifatu Państwa Islamskiego, określanej mianem Prowincji Afryki Zachodniej (Wilayat Gharb Afriqiya) (Spreading its tentacles; Islamic State, 2015, s. 37-38).

Nigeryjscy dżihadyści pod względem stosowanych metod walki są równie brutalni co bojownicy Państwa Islamskiego, zaś w sferze ideologicznej okazująjeszcze większą bezkompromisowość. Z tego względu społeczność międzynarodowa nie jest w stanie przewidzieć, jak rozwinie się ta organizacja. Organizacja, która zabiła już tysiące osób w walce o ustanowienia kalifatu, rzadko pokazuje także szacunek dla granic narodowych. Przekracza granicę sąsiednich państw w celu rekrutacji i szkolenia nowych bojowników, przez co stanowi zagrożenie nie tylko wewnątrzpaństwowe, ale i transnarodowe. Pomimo działań typowych dla organizacji przestępczych, pierwotnym celem ugrupowania jest utworzenie kalifatu we wszystkich stanach Nigerii. Obecnie szariat jest oficjalnym prawem jedynie w północnych jednostkach terytorialnych tego państwa, gdzie przeważająca część populacji wyznaje islam. Wydaje się, że tylko wzmożone działania państw sąsiednich i organizacji międzynarodowych mogą rozwiązać problem afrykańskiego kalifatu. Nie będzie to łatwe, ponieważ wojska Unii Afrykańskiej są już rozmieszczone na całym kontynencie - w Somalii, Republice Środkowoafrykańskiej i Mali, zaś Zachód w kwestii terroryzmu koncentruje się głównie na działaniach Państwa Islamskiego i zagrożeniach wewnątrz strefy euroatlantyckiej. W obliczu ataków terrorystycznych z 13 listopada 2015 roku w Paryżu działania mogą ulec pogłębieniu (Africa’s Islamic State; The fight against Boko Haram, 2015, s. 44).

Ponadto charakter działań terrorystycznych w Nigerii różni się od jego istoty w przypadku Afganistanu, Iraku, Pakistanu czy Syrii. Działalność terrorystyczna w państwie afrykańskim ma więcej wspólnego z taktyką stosowaną w działalno- 
ści zorganizowanych grup przestępczych i gangów, koncentrującą się na atakach z użyciem broni palnej czy broni białej, nie zaś na bombowych lub samobójczych atakach wykorzystywanych w przypadku innych, dużych grup terrorystycznych (w szczególności bliskowschodnich). Napaść z bronią jest przyczyną około $85 \%$ zgonów w Nigerii, podczas gdy zamachy i wybuchy bomb są odpowiedzialne za zaledwie 5 proc. zgonów. Ponadto ataki samobójcze są bardzo rzadkie, natomiast często dochodzi do porwań. W kwietniu 2014 roku, organizacja dokonała porwania 276 dziewcząt z miasta Chibok, (Global Terrorism Index Report, 2014; Nigeria and Boko Haram, The black flag in Africa, 2015). Ta różnica w stosunku do innych państw borykających się z problemem terroryzmu wynika z podziału wyznaniowego. W Nigerii muzułmanie stanowią 48,8 procent, podczas gdy chrześcijanie 49,3 procent. W Afganistanie, Iraku, Pakistanie i Syrii muzułmanie to znaczna większość - ponad 90 procent społeczeństwa (Table: Religious Composition by Country, in Percentages, 2012).

\section{IMPLIKACJE DLA BEZPIECZEŃSTWA MIĘDZYNARODOWEGO}

Islamski ekstremizm ma dwa główne, globalne centra. Jednym jest arabski Bliski Wschód, drugim zaś Afryka Subsaharyjska. Islamscy bojownicy stale zyskują wpływy i kontrolują znaczne połacie terytorium w tych regionach. Rosnąca izolacja północnej Nigerii podobna jest do wzorców zaobserwowanych w północnym Mali, w pakistańskich obszarach plemiennych oraz w południowo-wschodniej Somalii, znajdującej się pod kontrolą organizacji Asz-Szabaab (Al-Shabaab). Izolacja ta jest nie tylko problem północnej Nigerii, ale także posiada istotne znaczenie dla bezpieczeństwa regionalnego i międzynarodowego. Skomplikowana sytuacja w tym państwie i znaczna dynamika konfliktu pozwala stwierdzić, że na fali islamskiego militaryzmu i fanatyzmu Boko Haram zyskuje na znaczeniu nie tylko w Nigerii, ale także w regionie Sahelu, ponieważ w jej szeregach walczą bojownicy z Beninu, Czadu, Mauretanii, Nigru, Somalii i Sudanu (Siegle, 2013, s. $85-88)$.

Doświadczenia z innych części Afryki pokazują, że im dłużej trwa konflikt, tym większe jest prawdopodobieństwo, że kryzys się utrzyma bądź ulegnie intensyfikacji. Występuje również silne ryzyko przeniesienia konfliktu na inne państwa bądź regiony. W przypadku Nigerii może to oznaczać m.in., że:

- „odłamy” Boko Haram staną się jeszcze bardziej gwałtowne i radykalne politycznie; 
- przyspieszeniu ulegnie proces „rozlewania się” destabilizacji na państwa sąsiednie, a w dalszej perspektywie na cały region Afryki Subsaharyjskiej;

- wzrośnie liczba wysiedlonej i wygnanej ludności, przez co problem migracji w Afryce ulegnie pogłębieniu, a w konsekwencji wzrośnie również migracja do Europy a w zasadzie do zachodniej części kontynentu;

- Boko Haram nawiąże kontakty z transnarodowymi grupami przestępczymi w celu zwiększenia środków finansowych;

- wzrośnie liczba ataków terrorystycznych o podłożu religijnym w innych państwach Afryki i w innych regionach świata (Siegle, 2013, s. 85-88), co już obserwujemy;

- idee tworzenia kalifatów islamskich przeniesione zostaną na inne regiony.

Ponadto w związku z nasilającą się destabilizacją Nigeria, państwo o największym potencjale ludnościowym w Afryce - 158,4 mln (The Future of World Religions: Population Growth Projections, 2010-2050, s. 240), nie będzie w stanie pełnić wiodącej roli w regionie jako lidera inicjowania misji i operacji pokojowych, pokrywać obecnego zapotrzebowania na produkty rolne w regionie Sahelu czy wspomagać procesu demokratyzacji regionu.

Boko Haram w coraz większym stopniu zagraża również bezpieczeństwu międzynarodowemu. Brutalność działan Państwa Islamskiego sprawiła, że niektórzy uznają tę organizację za największe zagrożenie islamistyczne dla „wolnego świata”, znacznie przerastające nawet to, stwarzane do tej pory przez Al-Kaidę. Pomimo to rosnąca fala migracji oraz zagrożenie atakami terrorystycznymi na Zachodzie, potwierdzone paryskimi zamachami, w których zginęło ponad 120 osób, odwraca uwagę społeczności międzynarodowej od tej problematyki. Wszystko wskazuje na to, że kolejna organizacja rzuca wyzwanie nie tyko Zachodowi, ale wszystkim państwom, w szczególności tym o znacznym odsetku ludności muzułmańskiej. Atak na wioskę Baga pokazuje, że nigeryjscy islamiści są równie bezwzględni co bojownicy Państwa Islamskiego, a społeczność międzynarodowa nie jest w stanie przewidzieć, jak rozwinie się organizacja, w szczególności gdy osiągnie swój ostateczny cel - budowę kalifatu na całym terytorium Nigerii. Walka z afrykańskim samozwańczym państwem islamskim jest istotna dla sytuacji geopolitycznej całego regionu oraz kontynentu, a w dalszej perspektywie może pomóc w zwalczaniu podobnych zjawisk na całym świecie. 


\section{ZAKOŃCZENIE}

Media zachodnie koncentrują się głównie na działalności Państwa Islamskiego, ze względu na bliskość zagrożenia, potwierdzoną przez atak na redakcję francuskiego tygodnika satyrycznego Charlie Hebdo z 7 stycznia 2015 roku oraz serię ataków terrorystycznych w centrum Paryża z 13 listopada 2015 roku (Djadi, 2015). Jednakże zjawisko Państwa Islamskiego zasygnalizowało szerszą tendencję, mającą na celu tworzenie kalifatów w różnych częściach globu. Niektóre z najgroźniejszych islamskich grup bojowo-terrorystycznych, w najbardziej zdestabilizowanych regionach świata, m.in. afgańscy i pakistańscy Talibowie, somalijskie Asz-Szabab czy właśnie nigeryjskie Boko Haram, ewoluują w tym samym kierunku, a ich cele są bardzo zbliżone, choć dostrzegamy różnice w dobieranych przez te organizacje metodach i środkach walki, a więc strategii - drogi do ostatecznego celu, jakim jest ustanowienie globalnego kalifatu.

Rebelia Shekaua - spadkobiercy Yusufa, długo była uznawana jedynie za lokalny problem Nigerii, obecnie zachodni politycy i eksperci obawiają się, że kalifat opanuje najludniejszy kraj Afryki, zasobny w surowce naturalne, w tym ropę naftową. By określić kierunek ewolucji metod i środków przeciwdziałania zagrożeniu, konieczne jest, by społeczność międzynarodowa spostrzegła istotę połączenia dysfunkcyjnych lub upadających państw, głębokich podziałów regionalnych o podłożu historycznym oraz nieudolności ingerencji zewnętrznych, w tym działań organizacji międzynarodowych. Jest to niezwykle ważne, ponieważ możemy sądzić, że ten niepokojący trend w dążeniu do anektowania terytoriów przez ponadnarodowe grupy terrorystyczne w różnych regionach świata i tworzenia na nich kalifatów, w najbliższych latach może ulec znacznemu nasileniu. Natomiast dostosowanie strategii walki z afrykańskim państwem islamskim do geopolitycznych realiów regionu jest niezwykle trudnym zadaniem, co stale prezentuje przykład ekspansji Państwa Islamskiego, już nie tylko na obszarach Iraku i Syrii, ale także w innych państwach: Egipcie, Jemenie czy Libii.

\section{BiBLIOGRAFIA:}

Adebayo, A.A. (2014). Implications of 'Boko Haram' Terrorism on National Development in Nigeria: A Critical Review. Mediterranean Journal of Social Sciences, Vol. 5 (No 16).

Adibe, J. (2013). What do we really know about Boko Haram? W: I. Mantzikos (ed.), Boko Haram. Anatomy of Crisis. Bristol. Pobrano z: http://www.e-ir.info/wp-content/ uploads/Boko-Haram-e-IR.pdf. 
Africa's Islamic State; The fight against Boko Haram. The Economist, Vol. 414 (No. 8922). Altomonte, C., Ferrara M. (eds.) (2014). The Economic and Political Aftermath of the Arab Spring: Perspectives from Middle East and North African Countries. Cheltenham.

Bederka, A. (2014). Wahhabism and Boko Haram, Student Center for African Research and Resolutions. Pobrano z: http://www.scarrdc.org/uploads/2/6/5/4/26549924/ bederkawahhabism.pdf.

Blind to Bloodshed. The insurgency in Nigeria. The Economist, Vol. 414 (No. 8921).

Boko Haram at glance, Amnesty International. Pobrano z: http://www.amnesty.org/en/ news/boko-haram-glance-2015-01-29.

Boko Haram, The American Foreign Policy Council, August 21, 2013. Pobrano z: http:// almanac.afpc.org/sites/almanac.afpc.org/files/Boko\%20Haram\%20August $\% 20$ 2014_0.pdf.

Bulliet, R.W. (2013). Religion and the State in Islam. From Medieval Caliphate to Muslim Brotherhood. University of Denver: Center for Middle East Studies Occasional Paper Series Paper No. 2. Pobrano z: http://www.du.edu/korbel/middleeast/media/ documents/BullietPaperFinal.pdf.

Djadi, I. (2015). Paris attacks parallel fears over growing jihadist threat in Africa. World Watch Monitor. Pobrano z: https://www.worldwatchmonitor.org/2015/01/3620965/. Global Terrorism Index Report, Measuring and Understanding the Impact of Terrorism, Institute for Economics and Peace, 2014. Pobrano z: http://www.visionofhumanity. org/sites/default/files/ Global\%20Terrorism\%20Index\%20Report\%202014_0.pdf.

Nigeria and Boko Haram, The black flag in Africa, Jan 24, 2015, http://www.economist. com/news/leaders/21640348-only-if-government-tackles-misrule-and-endemiccorruption-will-jihadist-group-be.

Nigeria's jihadists. The other caliphate. The Economist, Vol. 412 (No. 8903).

Siegle, J. (2013). Boko Haram and the Isolation of Northern Nigeria: Regional and International Implications. W: I. Mantzikos (ed.). (2013). Boko Haram. Anatomy of Crisis. Bristol. Pobrano z: http://www.e-ir.info/wp-content/uploads/Boko-Haram-e-IR.pdf. Spreading its tentacles; Islamic State. The Economist, Vol. 416 (No. 8945).

Table: Religious Composition by Country, in Percentages, Dec 12, 2012. Pobrano z: http://www.pewforum.org/2012/12/18/table-religious-composition-by-countryin-percentages/.

The Future of World Religions: Population Growth Projections, 2010-2050, Pew Research Center, 2015. Pobrano z: http://www.pewforum.org/files/2015/03/PF_15.04.02_ProjectionsFullReport.pdf. 